\title{
COMPOSITE MIXTURE OF STONE DUST AND FLY ASH AS A SUBGRADE IN RURAL ROADS
}

\author{
S.Krishna Rao ${ }^{1}$, Bhanu Prakash ${ }^{2}$ \\ ${ }^{1}$ Associate Professor, Civil Engineering Department, V.R.Siddhartha Engineering College, Andhra Pradesh, India \\ ${ }^{2}$ B.Tech Student, Civil Engineering Department, SRK IT, Andhra Pradesh, India
}

\begin{abstract}
Fly ash is an industrial waste produced by the burning of coal in thermal power plants. From past years, fly ash is disposed in the form of landfills. Fly ash is an engineering material with unique properties. When compared with typical soils used for embankment construction, fly ash has large uniformity coefficient consisting of silt-sized particles mostly. Addition of Stone dust modifies the gradation of fly ash and also there will be an increase in unit weight of the composite material. This study has been carried out to know the possibility of using fly ash in combination with stone dust and lime or cement. The engineering properties of composite material (fly ash-stone dust-lime \cement) have been studied to bring out the possibility of using fly ash in the construction of embankments. Addition of stone dust to fly ash results in an increase in Maximum Dry Density (MDD), and at the same time observed a decrease in Optimum Moisture Content (OMC). Due to addition of stone dust, a significant increase in California Bearing Ratio (CBR) value is observed. The composite material consists of $60 \%$ fly ash $+40 \%$ of stone dust and $40 \%$ of fly ash $+60 \%$ of stone dust were further tested by adding lime. With addition of lime, there is a decrease in MDD and increase in the CBR value. The composite consisting of $40 \%$ fly ash $+60 \%$ stone dust with $2 \%$ lime resulted in a soaked CBR value of 9.0 at Maximum Dry Density (MDD) of $1.55 \mathrm{~g} / \mathrm{cm} 3$. This composite material may be used for the construction of subgrade for rural roads.
\end{abstract}

Keywords: Rural Roads, Fly Ash, MDD, OMC, CBR

\section{INTRODUCTION}

Fly ash is one of the industrial products obtained from combustion of coal. In the past decades, fly ash obtained from coal combustion was simply dumped into the atmosphere which caused many environmental and health hazards. More than $65 \%$ of fly ash produced is disposed of in landfills. India alone covers an area of 40,000acres (160 sq.km) with fly ash as landfills. Addition of fly ash stabilizes the soil, which in turn improves engineering performance of soil. On the other hand, Recycling fly ash includes environmental benefits such as reducing demand for virgin materials that would need quarrying and substituting materials which may be energy intensive to produce. This study has been undertaken to explore the possibility of use of fly ash with addition of stone dust and lime and also the engineering properties of the composite material (fly ash-stone dust-lime) have been studied. The discussion of results includes the possibility of use of fly ash in the construction of rural roads sub-grades. Beeghly (2003) showed in his study that a combination of lime and fly ash is beneficial for high silt content soils. Jirathanathworn and Chantawarangul (2003) reported that by use of fly ash mixed with small amount of lime, improves some of the engineering properties of the clayey soils including hydraulic conductivity as well as strength. Chauhan et al (2008) observed that with increase in percentage of fly ash mixed with stone dust there will be an increase in optimum moisture content and decrease in maximum dry density. In present days, about $10 \%$ of fly ash is utilized in ash dyke construction and land filling and only
$3 \%$ of ash is utilized in other construction industries. So far, the combination of fly ash, stone dust and lime has not been studied in detail.

\section{NEED FOR UTILIZATION AND SUBGRADE CHARACTERISTICS}

Fly ash causes environmental pollution, causing health hazards and disposal of fly ash requires large area. Fly ash possesses several desirable characteristics such as light weight, ease of compaction, faster rate of consolidation, better drainage, etc. Compaction process of fly ash can be started much earlier even after rainfall when compared to soil compaction process. Fly ash is a preferable material for the construction of embankments over weak sub soil. Subsequently, it is mandatory to use fly ash at all road works, located within a $100 \mathrm{~km}$ distance from a thermal power station (IRC:SP:20-2002). As per IRC guidelines (IRC:37-2001), on the basis of CBR values the sub-grade material may be classified as very poor for CBR value of 2 , poor for CBR value of 3-4, fair for CBR value of 5-6, good for $C B R$ value of 7-9 and very good for CBR value of 10 15.

IRC: SP: 89-2010 containing guidelines for soil, use of cement, lime and fly ash for material stabilization is important for selecting proper stabilized materials based on local soil. The objective of this experimental work is to develop a fly ash - stone dust - lime composite with CBR value greater than 10 (very good) preferably or at least in the range of 7-9 (good). 


\section{SCOPE AND OBJECTIVES}

A study was made to know the engineering properties of different proportions of fly ash, stone dust and lime, to know the possibility of using the composite for construction of sub-grades for rural roads. Fly ash is obtained from Dr.Narla Tata Rao Thermal Power Station, which is well renowned as V.T.P.S., Ibrahimpatnam and stone dust obtained from stone crushers.

The main objectives of the study are:

1. Geotechnical properties of fly ash and stone dust were determined individually and combinations with various proportions at regular intervals of $10 \%$.

2. Varying percentages of Fly ash and stone dust were mixed and maximum dry density and optimum moisture content of the mix were determined.

3. Hydrated lime in varying percentages of $2 \%, 4 \%$, $6 \%$ and $8 \%$ was mixed with three combinations of fly ash and stone dust in ratio of 60:40, 50:50 and 40:60 and compaction and California bearing ratio (CBR) tests were conducted.

4. The CBR value of the most appropriate combination of fly ash and stone dust with varying percentage of lime has been studied at the optimum moisture content and maximum dry density.

\section{ENGINEERING \\ PROPERTIES \\ OF}

\section{MATERIALS}

The materials used in this study include fly ash, stone dust and hydrated lime in the powder form. As per Indian Standard soil classification system, the stone dust was classified as well graded stone dust (SW). As per IS: 2720 (Part 4) 1975, the particle size distribution curves for fly ash, stone dust and their combinations are shown in Fig. 1. The basic properties of stone dust and fly ash are given in Table 1.

Table 1: Basic Properties of Stone dust and Fly ash

\begin{tabular}{|l|l|l|}
\hline Particulars of test & Stone dust & Fly ash \\
\hline Specific Gravity & 2.71 & 2.5 \\
\hline Coefficient of uniformity $\mathrm{Cu}$ & 11.3 & 4.0 \\
\hline Coefficient of curvature $\mathrm{Cc}$ & 1.04 & 1.0 \\
\hline IS Soil classification & $\mathrm{SW}$ & $\mathrm{SM}$ \\
\hline Liquid limit(\%) & - & 40.0 \\
\hline Plastic limit (\%) & - & $\mathrm{NP}$ \\
\hline MDD (g/cc) & 2.187 & 1.387 \\
\hline OMC(\%) & 5.9 & 18.2 \\
\hline Soaked CBR(\%) & 21.0 & 2.5 \\
\hline
\end{tabular}

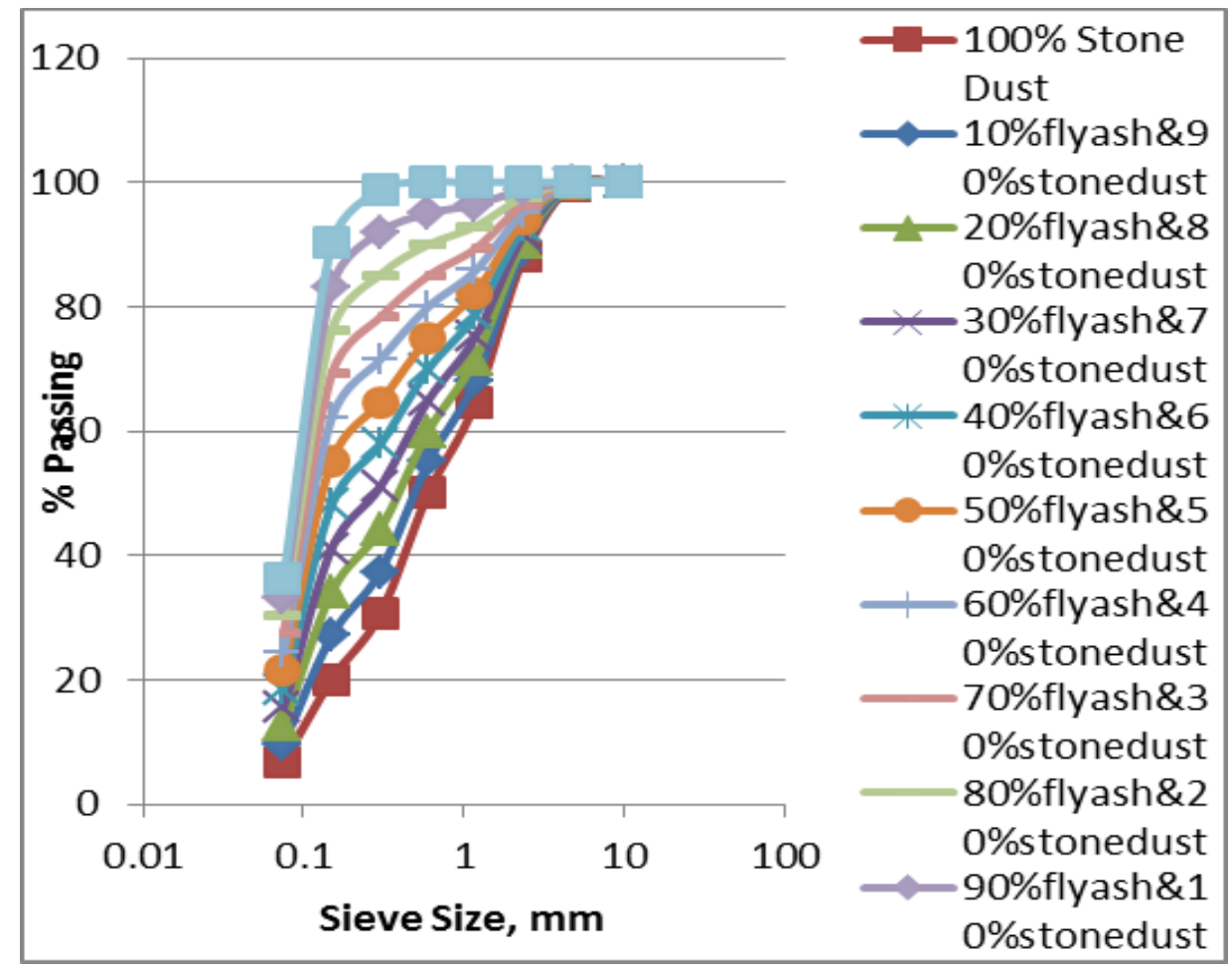

Fig. 1 Particle Size Distribution Curves of Stone dust, Fly ash and Stone dust + Fly ash Composite

\section{METHOD OF TESTING}

Laboratory tests were conducted as per Indian Standards in two phases:

1. Combination of stone dust with fly ash in varying percentages of $10 \%, 20 \%, 30 \%, 40 \%, 50 \%, 60 \%$, $70 \%, 80 \%$, and $90 \%$.
2. Combination of $50 \%$ stone dust and $50 \%$ fly ash for varying lime content in range of $2-8 \%$ with increment of $2 \%$.

The mixing was carried out manually and maximum care was taken to attain a uniform mix. The properties like moisture density relation (IS light compaction) and CBR for the stone dust blended with varying percentage of fly ash 
were determined. At the same time, effect of lime content (varying from $2 \%$ to $8 \%$ with increment of $2 \%$ ) for stone dust blended with $50 \%$ and $50 \%$ of fly ash on properties like moisture-density relation and CBR were determined.

\section{RESULTS AND DISCUSSION}

\subsection{Compaction Characteristics of Stone dust Fly}

\section{Ash Composite}

IS Light compaction tests were carried out for different proportions of stone dust and fly ash as per the procedure presented in IS: 2720 (Part7) 1980/87 in order to study the relationship between moisture and density.
The variation of dry density with water content for stone dust, fly ash and different combinations of stone dust and fly ash is presented in Fig., 2. From observations, Maximum Dry Density (MDD) increases with the increase in stone dust content; whereas the optimum moisture content decreases. This may be due to the higher specific gravity and coarser nature of stone dust than fly ash which leads to increase in MDD and the lower specific surface of stone dust leads to decrease in OMC.

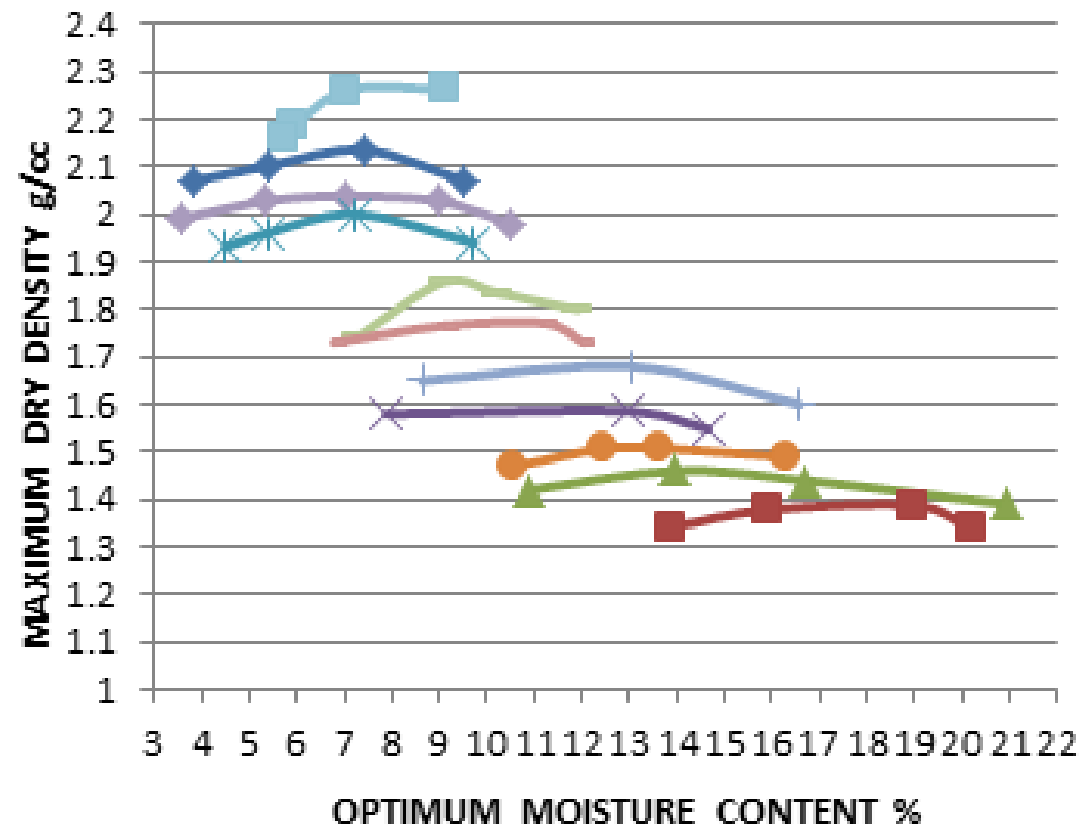

Fig. 2 variation of Dry Density of Stone dust with Fly ash Content

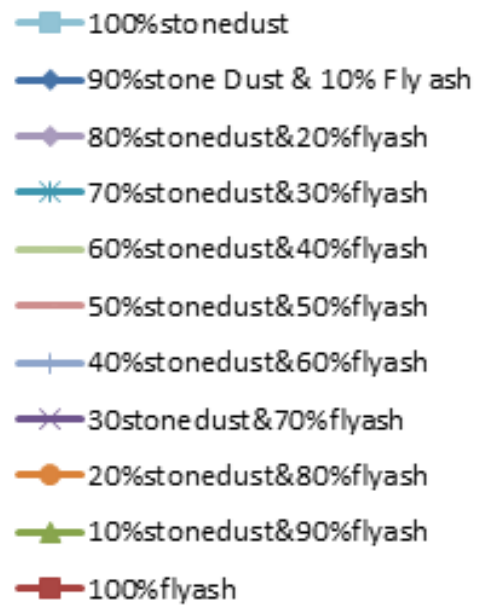

With increase in percentage of stone dust, the variation of Maximum Dry Density (MDD) and Optimum Moisture Content (OMC) is shown in Fig. 2. The variation in maximum dry density can be expressed in terms of linear relationship given by equation: 


\section{MDD}

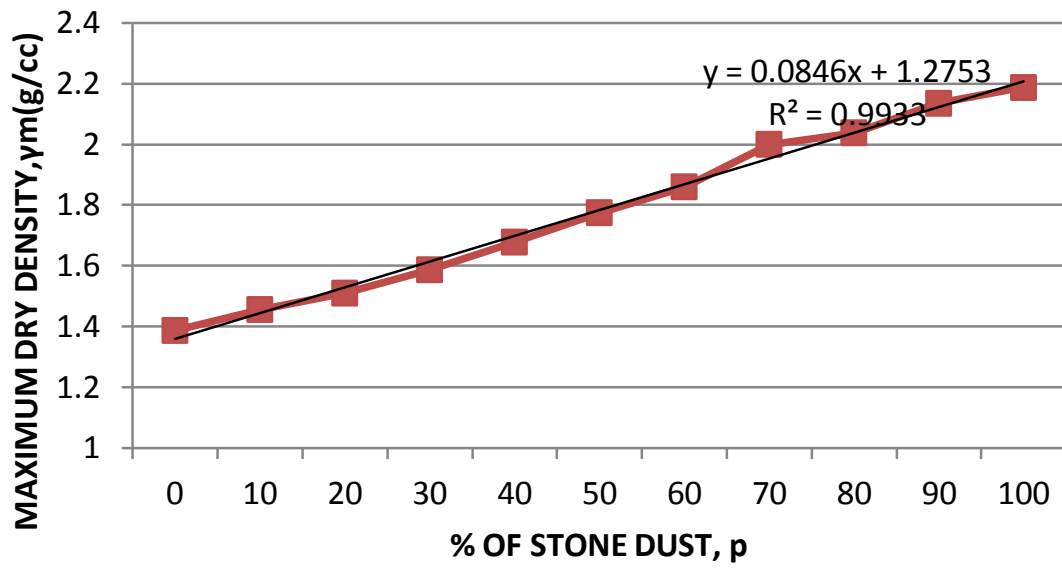

Fig. 3 Variation of MDD of Fly ash-Stone dust Composite

The Variation of Maximum Dry Density (MDD) can be expressed by the equation:

$$
\begin{gathered}
\gamma_{\mathrm{m}}=0.084 \mathrm{p}+1.275 \\
\mathrm{R}^{2}=0.993
\end{gathered}
$$

Where,

$\gamma_{\mathrm{m}}=$ Maximum Dry Density in $\mathrm{g} / \mathrm{cc}$ and

$\mathrm{p}=$ Percentage of Stone dust

The Variation of Optimum Moisture Content (OMC) can be expressed by the equation:

$$
\begin{gathered}
\mathrm{w}=-1.122 \mathrm{p}+17.44 \\
\mathrm{R}^{2}=0.942
\end{gathered}
$$

Where,

$\mathrm{w}=$ Percentage of Optimum Moisture Content and

$\mathrm{p}=$ Percentage of Stone dust

OMC

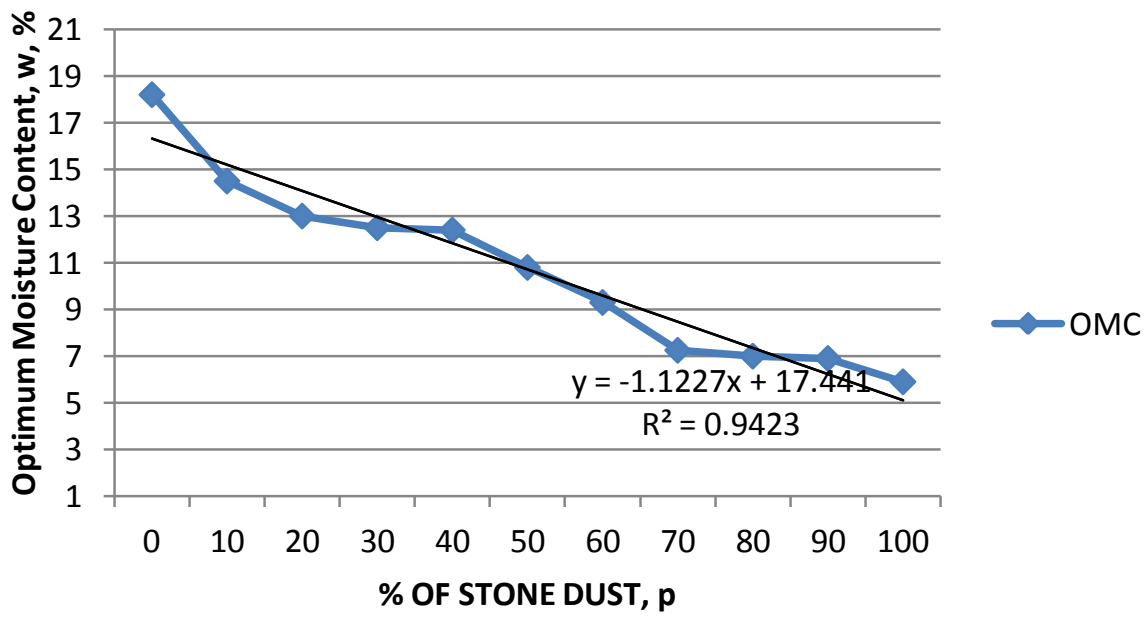

Fig. 4 Variation of OMC of Fly ash-Stone dust Composite 


\section{CONCLUSION}

Based upon the above study the following conclusions can be drawn:

1. With increase in Stone Dust to fly ash results in an increase in MDD with a decrease in OMC.

2. Following equation is proposed to obtain the OMC for given \% replacement of Stone Dust

$$
\mathrm{w}=-1.122 \mathrm{p}+17.44
$$

3. For Calculating the MDD with given $\%$ replacement of Stone dust, proposed equation is

$$
\gamma_{\mathrm{m}}=0.084 \mathrm{p}+1.275
$$

\section{REFERENCES}

[1] IRC: SP:20-2002,"Rural Roads Manual" Indian Road Congress, New Delhi ,India.

[2] IRC:37-2001,"Guidelines for the design of Flexible Pavements"

[3] R.K.Sharma, "subgrade characteristics of sand-fly ash- lime composite", Indian Highways, October 2014

\section{BIOGRAPHIES}

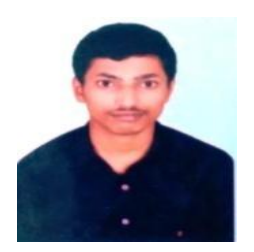

P.Bhanu Prakash - Presently Studying B.Tech Final Year in Civil Engineering in SRK Institute of Technology, Vijayawada

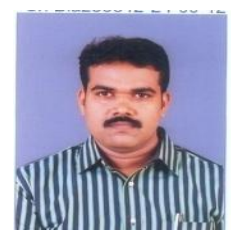

S.Krishna Rao-He Had Received B.Tech Degree from Bapatla Engineering College Bapatla and M.E. from S.G.S. Institute of Technology and Science, Indore. Presently he is pursuing Ph.D from JNTUH, Hyderabad 